\title{
Different amounts of protein-bound citrulline and homocitrulline in foot joint tissues of a patient with anti-citrullinated protein antibody positive erosive rheumatoid arthritis
}

\author{
Sanna Turunen ${ }^{1 *}$, Marja-Kaisa Koivula ${ }^{1,2}$, Jukka Melkko ${ }^{3,4}$, Eeva Alasaarela ${ }^{5}$, Petri Lehenkari, ${ }^{6,7}$ and Juha Risteli ${ }^{1,2}$
}

\begin{abstract}
Background: Antibodies binding to citrullinated proteins are a frequent finding in rheumatoid arthritis patients and may precede the onset of clinical symptoms several years. The antibodies are a predisposing factor for bone erosions but their origin is unknown. In this study we analyze in detail the levels of protein bound citrulline and homocitrulline in several tissue samples of a single erosive arthritic surgery patient.

Methods: Serum antibodies binding to CCP, MCV and citrulline- or homocitrulline-containing type I and II collagen carboxytelopeptides were measured. Tissue samples of a single RA patient, taken in two separate operations performed with two-year time span were hydrolyzed and analyzed for citrulline and homocitrulline content by HPLC.

Results: Protein-bound citrulline and homocitrulline were found in several joint tissues of a RA patient with ACPApositive erosive disease. The amount of homocitrulline stayed relatively constant between the different tissues. The amount of citrulline in erosive tissue was 3-times higher than in non-erosive tissue in the first operation. In the samples of the second operation 3-4-times higher mean amounts of citrulline were found in two out of the six tissues investigated.
\end{abstract}

Conclusions: Homocitrulline is present in rheumatoid nodule together with citrulline. There is more variation in the amount of citrulline than in the amount of homocitrulline between the tissues. The tissue sample containing the most citrulline was the most erosive.

Keywords: Citrulline, Homocitrulline, Rheumatoid arthritis, Autoantibodies, Tissue, Carbamylation

\section{Background}

Antibodies binding to citrullinated proteins are a frequent finding in rheumatoid arthritis (RA) patients and may precede the onset of clinical symptoms several years [1]. The anti-citrullinated protein antibodies (ACPA) are a predisposing factor for bone erosions in RA patients [2]. The ACPA antibody repertoire of RA patients has been quite specifically characterized [3-5] and possible candidate antigens for these antibodies have also been demonstrated in several studies [6-8]. Antibodies binding

\footnotetext{
* Correspondence: sanna.turunen@oulu.fi

'Department of Clinical Chemistry, Institute of Diagnostics, University of

Oulu, Oulu, Finland

Full list of author information is available at the end of the article
}

to carbamylated proteins have been found recently in RA sera [9] but the presence of homocitrulline-containing proteins in RA tissues have not been demonstrated yet. Recent studies on RA have suggested that the original antigen of ACPA could be in the lungs [10] or in the gingiva [11]. The inflammation of the joints is still the most prominent symptom and chronic joint inflammation resistant to medication is treated surgically. In this study we analyzed for the first time in detail the levels of protein bound citrulline and homocitrulline in several tissue samples of a single erosive arthritic surgery patient. 


\section{Patient and methods Patient}

47-year-old female RA patient with a disease history of 10 years, at the time of the first operation, described here due to difficult and resistant local symptoms at right MTP1 and MTP5 joints. Prior to this several operations were performed to remove synovitis and rheumatoid nodules from both hands. The patient used multiple medication, that included natriumaurothiomalate $50 \mathrm{mg}$ monthly, methotrexate $12.5 \mathrm{mg}$ once weekly, leflunomide $20 \mathrm{mg}$ daily and prednisolone $2.5 \mathrm{mg}$ daily. Tissue samples were collected from two separate operations with two-year time span (Figure 1A and B in the first operation and 1-6 in the second operation).

\section{Histology}

Samples were cut from the tissues (A, B and 1-6) frozen at $-70^{\circ} \mathrm{C}$, fixed in formalin and embedded in paraffin. 5 $\mu \mathrm{m}$ sections were mounted on glass slides and stained with hematoxyline-eosine.

\section{Assessment of autoantibodies in the patient serum}

Serum sample obtained at the time of the second surgery was analyzed for binding anti-CCP (Immunoscan RA (Mark 2) Euro Diagnostica, Malmö, Sweden) and anti-MCV (ORG 546, ORGANTEC Diagnostica GmbH, Mainz, Germany). Also antibodies binding to citrulline or homocitrulline containing collagen type I and II carboxytelopeptides were measured from the serum as described previously $[12,13]$.

\section{Detection of protein-bound citrulline and homocitrulline on high-performance liquid chromatography (HPLC)}

Six approximately $10 \mathrm{mg}$ (wet weight) samples were cut from each tissue. The samples were dialyzed $16 \mathrm{~h}$ against $0.2 \mathrm{M} \mathrm{NH}_{4} \mathrm{HCO}_{3}, \mathrm{pH} 7.4$ to separate free amino acids from protein-bound ones and freeze-dried, then rehydrated in distilled $\mathrm{H}_{2} \mathrm{O}$, freeze-dried and hydrolyzed in $6 \mathrm{M} \mathrm{HCl}$ at $110^{\circ} \mathrm{C}$ for $16 \mathrm{~h}$ and freeze-dried. The samples were chemically modified and analyzed on HPLC as reported previously [12]. The values for citrulline and homocitrulline in the sample were read from the automatically integrated peak area. The sample mass variation was taken in to account by using a correction coefficient.

\section{Statistical analysis}

The peak areas of citrulline and homocitrulline between tissues were assessed by independent samples MannWhitney $U$ test for the first operation tissues $(n=2)$ and by Kruskal-Wallis test for the second operation tissues $(\mathrm{n}=6)$ using Statistical Package for Social Science (SPSS) for Windows version 20 (IBM SPSS Statistics, Armonk, New York, USA). The differences were considered significant at $\mathrm{p}<0.05$.

\section{Ethical considerations}

The research plan was approved by the Ethics Committee of Oulu University Hospital, the guidelines of the Declaration of Helsinki were followed and an informed consent was signed by the patient.

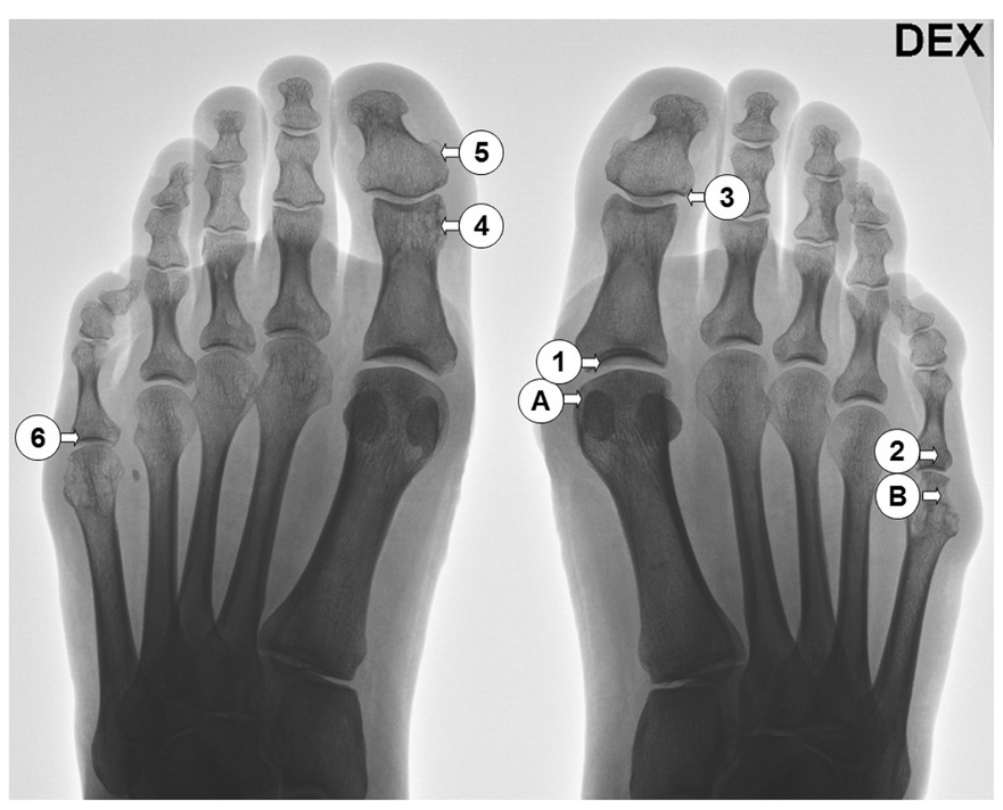

Figure 1 The patient radiograph taken before the first surgery. The locations of the samples taken are presented by $\mathbf{A}$ and $\mathbf{B}$ for the first operation and numbered from 1-6 for the second operation. 


\section{Results}

The patient was positive for antibodies binding to CCP $(800.5 \mathrm{U} / \mathrm{ml})$ and $\mathrm{MCV}(55.9 \mathrm{U} / \mathrm{ml})$ but no antibodies binding to citrulline- or homocitrulline-containing type I and II collagen carboxytelopeptides were detected. Tissue samples A and B (Figure 1) were collected during the first operative treatment to remove rheumatoid synovitis. Tissue B was from an area where the tissue was both visually and radiologically eroded. In histological studies the tissues were classified as rheumatoid nodules characterized by necrotic tissue surrounded by palisading macrophages. RA tissue consists of a mixture of various tissues, such as vascular, epithelial, different types of fibrotic and necrotic tissues. All samples were adjacent to synovium, hence some synovial fragments were present, as shown in Figure 2.

In the HPLC analysis of the first operation tissue samples the mean level of homocitrulline was lower and mean level of citrulline 3-times higher in the erosive $\mathrm{B}$ compared to the non-erosive tissue A (Figure 3). In the Mann-Whitney independent samples $U$ test both the differences in citrulline and in homocitrulline between tissues were statistically significant $(\mathrm{p}<0.001)$.

The second operation was scheduled after 2-years follow-up due to synovitis relapse. A more radical operation was programmed in consensus with the patient due to extensive synovial tissue growth in multiple sites and the aim was to remove all active synovitis and hence 6 separate cuts were made. Representative samples were taken from metatarsal joints (Figure 1: 1, 2,6) and from interphalangeal joints (Figure 1: 3, 4, 5). In HPLC analysis homocitrulline and citrulline were present in all samples. The level of homocitrulline stayed more constant between both operations and the different samples compared to citrulline (Figure 3). In the Kruskal-Wallis independent sample tests both the differences in citrulline and in homocitrulline levels between tissues of the second operation were statistically significant $\mathrm{p}=0.001$ and $\mathrm{p}=0.003$ respectively. In the pairwise comparison tissue number 5 differed statistically from tissues 1 and 2 with greater amount of homocitrulline $(\mathrm{p}=0.003$ and 0.022). The amount of citrulline in tissue number 4 was statistically greater than in tissues 1,2 and $6(\mathrm{p}=0.020$, 0.024 and 0.029 , respectively). Clinically the patient recovered from both surgeries without complications and the patient reported a significant reduction in RA symptoms and arthrodesis of the right MTP 1 joint was cancelled.

\section{Discussion}

In this study, we report the detailed analysis of proteinbound citrulline and homocitrulline in the RA affected tissues of a severely RA symptomatic patient. Citrulline and in experimental model also homocitrulline injected with adjuvant [12] can induce antibodies against citrullinated proteins that are a predisposing factor for erosive RA. We hypothesized that our systemically ACPA positive patient could have citrullinated proteins locally at the symptomatic site of intended surgery. The erosions were evident already in the first radiograph and repeated sampling from surgically removed synovitis tissue revealed citrullinated proteins in the tissues.

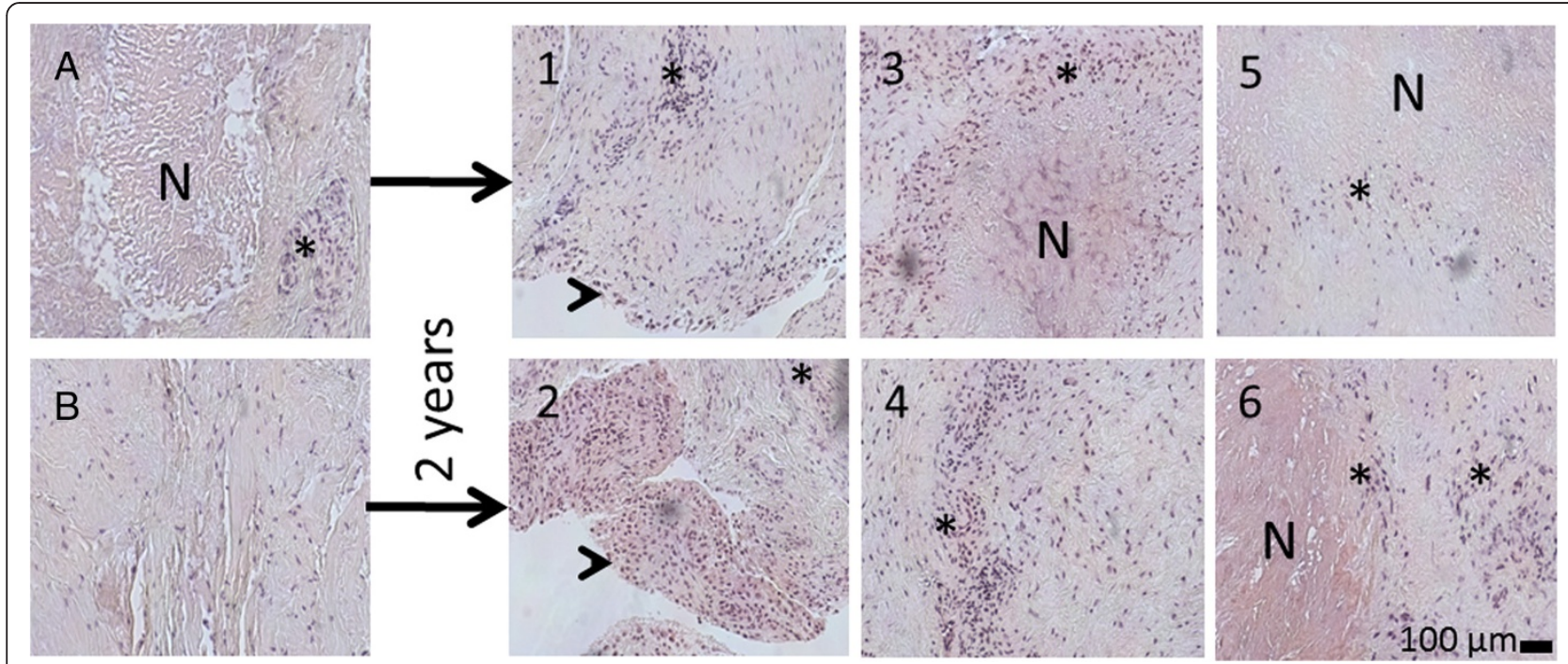

Figure 2 Histological images of removed tissues. Numbers correspond those shown in Figure 1. Interval between operations was 2 years, A and 1, B and 2 are samples from same anatomical site, respectively. Arrowheads indicate epithelial tissue, ${ }^{*}$ indicates inflammatory cells, mostly macrophages, $\mathrm{N}$ indicates necrosis in the rheumatoid nodulus. 

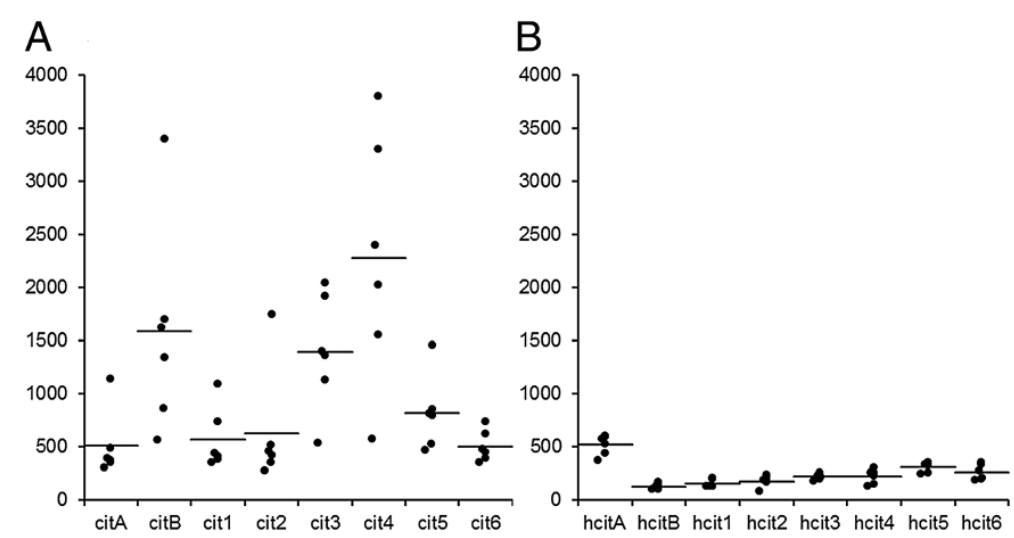

Figure 3 Results of the HPLC-analysis of citrulline and homocitrulline. The auto-integrated HPLC peak areas of A) citrulline and B) homocitrulline in the six samples analyzed from each of the eight removed foot joint tissues. In the first operation tissue $\mathbf{A}$ was non-erosive and tissue $\mathbf{B}$ was from an erosive location.

Homocitrulline was present in all samples but the level of homocitrulline was low compared to citrulline and stayed more constant between both operations and different tissues (Figure 3A and B). In the postoperative surgical interview the subjective general and especially the feet symptoms caused by RA were alleviated by the removal of the diseased tissue. However, it is of interest that the clinical symptoms were only alleviated after the second, more thorough operation. This suggests that although the primary induction of the ACPA might be elsewhere the removal of the citrulline and homocitrulline containing tissues affects the local disease activity. The local presentation of the citrullinated antigens could be a reason for erosion. Lately osteoclastogenesis and bone loss induced by antibodies binding to citrullinated vimentin was demonstrated [14]. Interestingly the PAD expression pattern in osteoclasts is similar that is found in the macrophages of the inflamed RA synovium $[15,16]$. The bone loss in RA is not exclusive consequence of synovitis, but neither ACPA alone is enough to cause classical bone erosions [17].

Antibodies binding to carbamylated proteins were recently found in RA patient sera [9]. The presence of homocitrulline, the product of lysine carbamylation, however, has not been demonstrated earlier in RA tissues. The relevance of homocitrulline to RA pathogenesis is not clear, but at least in animal model protein-bound homocitrulline injected with adjuvant was able to induce antibodies binding to citrullinated proteins [12]. Carbamylation can be caused by inflammation [18] or ageing of tissues [19]. Therefore the differences between our samples could be explained by two alternative ways explaining either the low or the high homocitrulline level. High level of homocitrulline could be a consequence of the chronic inflammation related to RA. On the other hand a low level of homocitrulline could be explained by repair that creates the RA synovitis tissue as the newly formed tissue has not gained age-related posttranslational modifications like the lysine carbamylation to homocitrulline. The highest homocitrulline value was from MTP 1 joint (A) that was the most symptomatic and the primary cause for the first surgical intervention. Bearing this in mind, tissue $B$ was highly interesting because it had the lowest level of homocitrulline and high level of citrulline and the tissue was highly erosive. This would suggest presence of an active disease process with increased citrullination in the newly formed tissue. Recently, neutrophil extracellular traps were suggested as the source of citrullinated antigens in RA [20]. We could not detect any neutrophils in the basic histological analysis of the nodules, only macrophages and a few plasma cells, though the presence of citrulline in the chemical analysis was evident.

As limitations for this case report, it should be noted that the results gained do not necessarily reflect the situation in other tissue specimens, such as larger joints or in other RA patients. Also it is notable, that the amount of citrulline and homocitrulline in each sample was affected by the exact location, where the $10 \mathrm{mg}$ sample was taken because all specimens were analyzed separately. Rheumatoid nodules are not uniform, they consisted of various amounts of necrosis that was surrounded by different amount of mainly macrophages and other inflammatory cells, such as lymphocytes so even the same tissue contained areas that had different levels of each amino acid. For this same reason the appearance of the tissue (inflammation and necrosis) could not be correlated with the HPLC analysis results.

\section{Conclusions}

This is the first study analyzing in detail the significant local differences in citrulline and homocitrulline content of several tissues of a single ACPA-positive patient with erosive RA and showing the presence of homocitrulline in rheumatoid nodule tissues. 


\section{Abbreviations}

RA: Rheumatoid arthritis; ACPA: Anti-citrullinated protein antibodies; AntiCCP: Anti-cyclic citrullinated peptide (clinical assay); Anti-MCV: Anti-mutated citrullinated vimentin (clinical assay); HPLC: High performance liquid chromathography; MTP: Metatarsophalangeal (joint).

\section{Competing interests}

The authors declare that they have no competing interests.

\section{Authors' contributions}

ST, MKK, PL and JR contributed to study design. PL operated the patient and collected samples. ST carried out the immunoassays and HPLC analysis. JM conducted the histological analysis. EA did the rheumatological evaluation of the patient. ST and PL drafted the manuscript. All authors revised the manuscript and read and approved the final version.

\section{Acknowledgements}

This study was supported by the National Doctoral Programme of Musculosceletal Disorders and Biomaterials (ST), The Academy of Finland (MKK, JR), Finnish Society of Clinical Chemistry (MKK).

\section{Author details}

${ }^{1}$ Department of Clinical Chemistry, Institute of Diagnostics, University of Oulu, Oulu, Finland. ${ }^{2}$ Northern Finland Laboratory Centre NordLab, Oulu University Hospital, Oulu, Finland. ${ }^{3}$ Department of Pathology, Institute of Diagnostics, University of Oulu, Oulu, Finland. ${ }^{4}$ Department of Pathology, Oulu University Hospital, Oulu, Finland. ${ }^{5}$ Department of Internal Medicine, Division of Rheumatology, Oulu University Hospital, Oulu, Finland. ${ }^{6}$ Department of Anatomy and Cell Biology, Institute of Biomedicine, University of Oulu, Oulu, Finland. ${ }^{7}$ Surgery Clinic, Oulu University Hospital, Oulu, Finland.

Received: 22 May 2013 Accepted: 17 September 2013

Published: 23 September 2013

\section{References}

1. Koivula MK, Heliovaara M, Ramberg J, Knekt P, Rissanen H, Palosuo T, Ristel J: Autoantibodies binding to citrullinated telopeptide of type II collagen and to cyclic citrullinated peptides predict synergistically the development of seropositive rheumatoid arthritis. Ann Rheum Dis 2007, 66:1450-1455.

2. Lundberg K, Nijenhuis S, Vossenaar ER, Palmblad K, van Venrooij WJ, Klareskog L, Zendman AJ, Harris HE: Citrullinated proteins have increased immunogenicity and arthritogenicity and their presence in arthritic joints correlates with disease severity. Arthritis Res Ther 2005, 7:R458-R467.

3. Nielen MM, van Schaardenburg D, Reesink HW, van de Stadt RJ, van der Horst-Bruinsma IE, de Koning MH, Habibuw MR, Vandenbroucke JP, Dijkmans BA: Specific autoantibodies precede the symptoms of rheumatoid arthritis: a study of serial measurements in blood donors. Arthritis Rheum 2004, 50:380-386.

4. Suwannalai $P$, Trouw LA, Toes RE, Huizinga TW: Anti-citrullinated protein antibodies (ACPA) in early rheumatoid arthritis. Mod Rheumato/ 2012, 22:15-20.

5. van de Stadt LA, de Koning MH, van de Stadt RJ, Wolbink G, Dijkmans BA, Hamann D, van Schaardenburg D: Development of the anti-citrullinated protein antibody repertoire prior to the onset of rheumatoid arthritis. Arthritis Rheum 2011, 63:3226-3233.

6. Lundberg K, Kinloch A, Fisher BA, Wegner N, Wait R, Charles P, Mikuls TR, Venables PJ: Antibodies to citrullinated alpha-enolase peptide 1 are specific for rheumatoid arthritis and cross-react with bacterial enolase. Arthritis Rheum 2008, 58:3009-3019.

7. Koivula MK, Aman S, Karjalainen A, Hakala M, Risteli J: Are there autoantibodies reacting against citrullinated peptides derived from type I and type II collagens in patients with rheumatoid arthritis? Ann Rheum Dis 2005, 64:1443-1450.

8. Masson-Bessiere C, Sebbag M, Girbal-Neuhauser E, Nogueira L, Vincent C, Senshu T, Serre G: The major synovial targets of the rheumatoid arthritisspecific antifilaggrin autoantibodies are deiminated forms of the alphaand beta-chains of fibrin. $J$ Immunol 2001, 166:4177-4184.

9. Shi J, Knevel $R$, Suwannalai $P$, van der Linden MP, Janssen $G M$, van Veelen PA, Levarht NE, van der Helm-van Mil AH, Cerami A, Huizinga TW, Toes RE,
Trouw LA: Autoantibodies recognizing carbamylated proteins are present in sera of patients with rheumatoid arthritis and predict joint damage. Proc Natl Acad Sci U S A 2011, 108:17372-17377.

10. Klareskog L, Stolt P, Lundberg K, Kallberg H, Bengtsson C, Grunewald J, Ronnelid J, Harris HE, Ulfgren AK, Rantapaa-Dahlqvist S, Eklund A, Padyukov $L$, Alfredsson $L$ : A new model for an etiology of rheumatoid arthritis: smoking may trigger HLA-DR (shared epitope)-restricted immune reactions to autoantigens modified by citrullination. Arthritis Rheum 2006, $54: 38-46$.

11. Nesse W, Westra J, van der Wal JE, Abbas F, Nicholas AP, Vissink A, Brouwer $\mathrm{E}$ : The periodontium of periodontitis patients contains citrullinated proteins which may play a role in ACPA (anti-citrullinated protein antibody) formation. J Clin Periodontol 2012, 39:599-607.

12. Turunen S, Koivula MK, Risteli L, Risteli J: Anticitrulline antibodies can be caused by homocitrulline-containing proteins in rabbits. Arthritis Rheum 2010, 62:3345-3352.

13. Koivula MK, Aman S, Alasaarela E, Karjalainen A, Hakala M, Risteli J: Inhibitory characteristics of citrullinated telopeptides of type I and II collagens for autoantibody binding in patients with rheumatoid arthritis. Rheumatology (Oxford) 2006, 45:1364-1369.

14. Harre U, Georgess D, Bang H, Bozec A, Axmann R, Ossipova E, Jakobsson PJ, Baum W, Nimmerjahn F, Szarka E, Sarmay G, Krumbholz G, Neumann E, Toes R, Scherer HU, Catrina Al, Klareskog L, Jurdic P, Schett G: Induction of osteoclastogenesis and bone loss by human autoantibodies against citrullinated vimentin. J Clin Invest 2012, 122:1791-1802.

15. Foulquier C, Sebbag M, Clavel C, Chapuy-Regaud S, Al Badine R, Mechin MC, Vincent C, Nachat R, Yamada M, Takahara H, Simon M, Guerrin M, Serre G: Peptidyl arginine deiminase type 2 (PAD-2) and PAD-4 but not PAD-1, PAD-3, and PAD-6 are expressed in rheumatoid arthritis synovium in close association with tissue inflammation. Arthritis Rheum 2007 56:3541-3553.

16. Chang X, Yamada R, Suzuki A, Sawada T, Yoshino S, Tokuhiro S, Yamamoto K: Localization of peptidylarginine deiminase 4 (PADI4) and citrullinated protein in synovial tissue of rheumatoid arthritis. Rheumatology (Oxford) 2005, 44:40-50.

17. Kleyer A, Finzel S, Rech J, Manger B, Krieter M, Faustini F, Araujo E, Hueber AJ, Harre U, Engelke K, Schett G: Bone loss before the clinical onset of rheumatoid arthritis in subjects with anticitrullinated protein antibodies. Ann Rheum Dis 2013. Published online first, doi:10.1136/annrheumdis-2012202958.

18. Wang Z, Nicholls SJ, Rodriguez ER, Kummu O, Horkko S, Barnard J, Reynolds WF, Topol EJ, DiDonato JA, Hazen SL: Protein carbamylation links inflammation, smoking, uremia and atherogenesis. Nat Med 2007, 13:1176-1184

19. Jaisson S, Gillery P: Evaluation of nonenzymatic posttranslational modification-derived products as biomarkers of molecular aging of proteins. Clin Chem 2010, 56:1401-1412.

20. Khandpur R, Carmona-Rivera C, Vivekanandan-Giri A, Gizinski A, Yalavarthi S, Knight JS, Friday S, Li S, Patel RM, Subramanian V, Thompson P, Chen P, Fox DA, Pennathur S, Kaplan MJ: NETs Are a Source of Citrullinated Autoantigens and Stimulate Inflammatory Responses in Rheumatoid Arthritis. Sci Transl Med 2013, 5:178ra40.

\section{doi:10.1186/1479-5876-11-224}

Cite this article as: Turunen et al:: Different amounts of protein-bound citrulline and homocitrulline in foot joint tissues of a patient with anticitrullinated protein antibody positive erosive rheumatoid arthritis. Journal of Translational Medicine 2013 11:224. 